\title{
New Aspects of Neurotransmitter Releasee and Exocytosis: Regulation of Neurotransmitter Release by Phosphorylation
}

\author{
Masami Takahashi ${ }^{1,2, *}$, Makoto Itakura ${ }^{1}$, and Masakazu Kataoka ${ }^{3}$ \\ ${ }^{1}$ Department of Biochemistry, Kitasato University School of Medicine, \\ 1-15-1 Kitasato, Sagamihara-shi, Kanagawa 228-8555, Japan \\ ${ }^{2}$ CREST, JST (Japan Science and Technology) \\ ${ }^{3}$ Department of Enviromental Science and Technology, Faculty of Engineering, Shinshu University, \\ Wakasato 4-17-11, Nagano-shi, Nagano 380-8553, Japan
}

Received May 2, 2003; Accepted June 27, 2003

\begin{abstract}
Synaptic transmission is conducted by neurotransmitters released from nerve terminals. Neurotransmitter release is regulated both positively and negatively by multiple mechanisms, and its regulation is believed to be one of the important mechanisms of synaptic plasticity underlying learning and memory. Various protein kinases play important roles in the regulation, and candidates for protein substrates essential for the regulation have been identified.
\end{abstract}

Keywords: neurotransmitter release, phosphorylation, protein kinase C, exocytosis

\section{Introduction}

Synaptic transmission is conducted by neurotransmitters released from nerve terminals. Neurotransmitter release is regulated both positively and negatively by multiple mechanisms and its regulation is believed to be one of the important mechanisms of synaptic plasticity underlying learning and memory. In the short-term, various protein kinases have been implicated in presynaptic regulation in a wide range of neuronal preparations; however, the precise mechanisms are still poorly understood.

\section{Elementary steps of neurotransmitter release}

Neurotransmitters are stored in synaptic vesicles and released into the synaptic cleft by exocytosis of vesicle contents, which involves docking and fusion of the vesicle membrane with the presynaptic plasma membrane. Recent studies revealed that the SNARE protein family, including syntaxin, SNAP-25, and vesicle-associated membrane protein (VAMP, also called synaptobrevin), plays an essential role in promoting membrane fusion, and it is thought to comprise the basic fusion machinery (1). SNARE proteins form a stable ternary

*Corresponding author. FAX: +81-42-778-8441

E-mail: masami@med.kitasato-u.ac.jp complex consisting of a twisted four-helix bundle linking the vesicle to the plasma membrane. The formation of SNARE complex is essential for neurotransmitter release and bacterial neurotoxins such as Clostridium botulinum neurotoxins and tetanus toxin inhibit neurotransmitter release by selective and specific proteolysis of SNARE proteins (2).

Neurotransmitter release is triggered by $\mathrm{Ca}^{2+}$ ions, and synaptotagmin is a candidate $\mathrm{Ca}^{2+}$ sensor for exocytosis (3). Thirteen synaptotagmin isoforms are expressed in mammalian tissue, and synaptotagmin 1 plays a principal role in presynaptic terminals of neurons. Synaptotagmins contain a single $\mathrm{N}$-terminal transmembrane region, a linker sequence, and two conserved $\mathrm{C} 2$ domains. In most synaptotagmins, both $\mathrm{C} 2$ domains bind multiple $\mathrm{Ca}^{2+}$ ions in a complex with phospholipids, and additionally form $\mathrm{Ca}^{2+}$-dependent complexes with SNARE proteins. $\mathrm{Ca}^{2+}$-dependent phospholipids binding to the $\mathrm{C} 2 \mathrm{~B}$ domain is essential for $\mathrm{Ca}^{2+}$ triggering of fast exocytosis (4); however, a key question of how $\mathrm{Ca}^{2+}$ binding to synaptotagmin 1 triggers fast release remains unanswered. In addition to the triggering of synaptic vesicle fusion, $\mathrm{Ca}^{2+}$ seems to regulate several other steps in neurotransmitter release. Calmodulin is suggested to be involved in the regulation of exocytosis in endocrine cells, but the precise mechanism of action remains to be clarified $(5-7)$. 
Electrophysiological evidences show that there are functionally distinct pools of vesicles in the nerve terminal and in adrenal chromaffin cells. One is a readily releasable pool (RRP), in which vesicles can be triggered for fusion in response to $\mathrm{Ca}^{2+}$, and another is a reserve pool (RP), in which vesicles are not $\mathrm{Ca}^{2+}$-responsible $(8,9)$. By using digitonin-permeabilized adrenal chromaffin cells, $\mathrm{Ca}^{2+}$-induced catecholamine release was shown to be divided into at least two sequential steps: a MgATP-dependent priming step and MgATPindependent $\mathrm{Ca}^{2+}$ triggered step (10). Several possibilities for the usage of ATP have been postulated, which include an ATP-dependent dissociation of the SNARE complex by NSF/SNAPs $(11,12)$, a production of phosphatidylinositol 4,5-bisphosphate by phosphatidylinositol-4-phosphate 5-kinase (13), and a protein phosphorylation by myosin light chain kinase (14). It is likely that there are several different steps in the priming process, and several different proteins may be involved in each step. Munc13 is identified as an essential component of the ATP-independent priming step in adrenal chromaffin cells (15).

\section{Regulation of neurotransmitter release by phospho- rylation}

In the short term, various protein kinases have been implicated in regulation of neurotransmitter release $(16,17)$. Cyclic AMP-dependent protein kinase (PKA), protein kinase $\mathrm{C}(\mathrm{PKC})$, and $\mathrm{Ca}^{2+}$ - and calmodulindependent protein kinase II stimulate neurotransmitter release in a wide range of neuronal preparations as well as in endocrine cells. Recent studies showed that mitogen-activated protein kinase $(18,19)$ and cyclin-dependent protein kinase 5 (20) and a lipid kinase such as phosphatidylinositol 3-kinase $(19,21)$ regulated neurotransmitter release positively. Generally, all regulatory systems have a set of both positive and negative regulators; however, no protein kinases involved in negative regulation had been reported so far. Recently, two types of non-receptor protein tyrosine kinases were found to be negative regulators of neurotransmitter release (22). Thus, it is obvious that neurotransmitter release is multiply regulated by various protein kinases, and all the elementary steps of exocytotic process can be modulated by the phosphorylation. In the following sections, we will focus on the regulatory roles of PKC, which is one of the most studied among various kinds of kinases, in the regulation of neurotransmitter and hormone release.

\section{PKC-mediated neurotransmitter release from neu- rons and endocrine cells}

$\mathrm{PKC}$ is $\mathrm{Ca}^{2+}$ and phospholipids-dependent kinase and eleven mammalian isoforms of PKC have been identified to date. The isozymes have been subdivided into three subclasses, conventional, novel, and atypical PKC, based on their structure and properties (23). PKC is highly expressed in brain and distributes differently in neurons in isozyme-specific manners. All PKC isozymes contain one or two cysteine-rich domains (CRDs) near the amino-terminal and diacylglycerol and phorbol ester binding to CRD activates PKC activity with the exceptions of atypical PKC. Phorbol ester induced a profound enhancement of neurotransmitter release from a wide variety of neuronal preparation $(24,25)$, and it had been widely believed that phorbol ester stimulates neurotransmitter release through the activation of PKC. However, a PKC inhibitor suppressed phorbol ester-induced potentiation of neurotransmitter release only partially $(26,27)$, and nonkinase proteins having CRD and phorbol ester binding activity are identified in mammalian tissues $(28,29)$. Thus, it is now believed that that phorbol ester potentiates neurotransmitter release through two distinct mechanisms, one phosphorylation-dependent and the other phosphorylation-independent. Quite a similar situation occurs in cAMP-dependent potentiation of neurotransmitter release. As described above, cAMP enhances neurotransmitter release from various neuronal cells and most of the cAMP action had attributed to the binding of cAMP to PKA. However, the cAMP-regulated guanine nucleotide exchange factor of Rap1A was found to mediate cAMP-induced, $\mathrm{Ca}^{2+}$-dependent secretion that was not blocked by an inhibitor of PKA (30). Thus, cAMP is also likely to activate neurotransmitter release through a phosphorylation-dependent mechanism and a phosphorylation-independent mechanism.

\section{Phosphorylation-independent potentiation of neuro- transmitter release by phorbol ester}

Munc13-1 is brain-specific protein essential for neurotransmitter release and is specifically localized to presynaptic terminals. It contains a diacylglycerol/phorbol ester binding CRD and two C2-domains homologous to the $\mathrm{Ca}^{2+}$-binding regulatory region of PKCs $(31,32)$. Munc13-1 interacts with syntaxin 1 and with DOC2, a $\mathrm{C} 2$-domain-containing protein of the putative regulator of neurotransmitter release $(33,34)$. Genetic disruption of Munc13-1 results in a depletion of synaptic vesicles in RRP and a loss of neurotransmitter releasing activity (32). Overexpression of Munc13-1 in adrenal chromaf- 
fin cells causes a marked increase in $\mathrm{Ca}^{2+}$-induced burst and the following steady state release of catecholamine, suggesting that Munc13-1 plays an essential role in the priming step after vesicle docking (15). Phorbol esterinduced potentiation of glutamate release was restored by transfecting Munc13-1 into Munc13-1/Munc13-2 double knock out mouse, but not by Munc13-1 which is lacking phorbol ester binding activity due to a point mutation of essential amino acid (35). These results indicate that Munc13s are the main presynaptic diacylglycerol/phorbol ester receptors, and they play an essential role in phorbol ester-induced potentiation of glutamate release from cultured rat hippocampal neurons.

\section{Phosphorylation-dependent potentiation of neuro- transmitter release by phorbol ester}

Many pharmacological experiments show that PKC inhibitors suppress phorbol ester-induced potentiation of neurotransmitter release in a wide range of neuronal preparations, suggesting the existence of a phosphorylation-dependent mechanism by PKC (24). The cellular mechanism was successfully revealed in adrenal chromaffin cells and in clonal rat pheochromocytoma PC12 cells. The number of $\mathrm{Ca}^{2+}$-responsible secretory vesicles was increased after phorbol ester treatment without significant changes in intracellular $\mathrm{Ca}^{2+}$ transient (36). Imaging analysis of secretory vesicles in living adrenal chromaffin cells and PC12 cells shows that the secretory vesicles translocate to the plasma membrane after phorbol ester-treatment in phosphorylation-dependent manners $(37,38)$. Thus, it is very likely that exocytosis of secretory vesicles of these cells are regulated by two distinct mechanisms, and PKC-dependent and phosphorylation-independent mechanisms are involved in steps before and after docking of vesicles to the plasma membrane, respectively.

Mechanisms of PKC-dependent regulation of neurotransmitter release seem to be different among different preparations. Activation of PKC enlarges RRP of vesicles in hippocampal neurons (39), whereas it seems to increase the $\mathrm{Ca}^{2+}$ sensitivity of secretion rather than RRP size in chick ciliary ganglion (40), the calyx of Held (41), and pituitary gonadotropes (42).

\section{Identification of protein substrate of PKC}

It is quite important to identify the protein substrate of PKC which is indispensable for the regulation of neurotransmitter release. Of the three neuronal SNAREs only SNAP-25 is phosphorylated by PKC in PC12 cells (43). The phosphorylation site is $\operatorname{Ser}^{187}$ in the C-terminal end of SNAP-25 between the cleavage sites for botulinum neurotoxin $\mathrm{A}$ and $\mathrm{E}$. The phosphorylation of SNAP-25 was confirmed by an immunoblotting using a specific antibody for SNAP-25 phosphorylated at $\operatorname{Ser}^{187}$ (27). Phosphorylation of SNAP-25 at $\operatorname{Ser}^{187}$ is also observed in cultured hippocampal neurons (35) and in rat insulinoma INS-1 cells and rat islets (44). Quite interestingly, phosphorylation was induced in $\mathrm{PC} 12$ cells by treatment with nerve growth factor (45) and in hippocampal neurons by long-term potentiation induction (46), suggesting that the phosphorylation plays an important role for brain function. No correlation between phorbol ester-induced phosphorylation of SNAP-25 and secretion were observed in PC12 cells (27) and in insulin-secreting cells (44). However, recent electrophysiological measurement with high timeresolution techniques revealed that the phosphorylation of SNAP-25 at Ser ${ }^{187}$ constitute a link between secretory activity and vesicle pool refilling in adrenal chromaffin cells (47).

The myristoylated alanine-rich C-kinase substrate (MARCKS) is a major cellular substrate of PKC widely distributed in mammalian cells. Phorbol ester-treatment of adrenal chromaffin cells induces a disruption of cortical F-actin and an increase in the number of secretory vesicles at the releasing site as well as the initial rate of stimulated catecholamine release (48). A synthetic peptide having the sequence of MARCKS phosphorylation site suppresses phorbol ester-induced phosphorylation of MARCKS, disassembly of F-actin, and stimulation of catecholamine release in membrane permeabilized adrenal chromaffin cells. These results suggest that PKC-dependent phosphorylation of MARCKS is involved in the regulation of the rapid phase of catecholamine release (49). Phorbol ester enhances glutamate and cholecystokinin releases from rat brain synaptosomes induced by the $\mathrm{K}^{+}$channel blocker 4aminopyridine but not by high- $\mathrm{K}^{+}$stimulation (50). Aspartic acid release by electronic stimulation from cultured cerebellar granule cells is enhanced by phorbol ester but not that by high- $\mathrm{K}^{+}$stimulation (51). These results suggest that suppression of the $\mathrm{K}^{+}$channel by $\mathrm{PKC}$ is crucial for the regulation; however, it is not yet determined whether the $\mathrm{K}^{+}$channel or another associating protein is a substrate of PKC. It was also reported that Munc-18 (52), GAP-43 (53), and rabphilin-3A (54) are phosphorylated by $\mathrm{PKC}$ in brain. However, it remains to be elucidated whether these phosphorylations are involved in the regulation of neurotransmitter release in brain. 


\section{Conclusion}

As we discussed above, many kinds of protein kinase may regulate neurotransmitter release from neurons and endocrine cells. However, the following questions still remain: 1) Which $\operatorname{step}(\mathrm{s})$ of neurotransmitter release is regulated by these kinases? 2) What is the protein substrate essential for the regulation? 3) What is the mechanism for regulation of the secretory machinery? 4) What is the physiological difference of the phosphorylation by different kinases? It is also possible that the distribution of kinases in presynaptic terminals are variable among different kinds of kinase, and the distribution may change in response to neuronal activity, which causes a long-lasting change in the properties of presynaptic functions. Further studies will be needed to answer these questions.

\section{References}

1 Lin RC, Scheller RH. Mechanisms of synaptic vesicle exocytosis. Annu Rev Cell Dev Biol. 2000;16:19-49.

2 Schiavo G, Rossetto O, Tonello F, Montecucco C. Intracellular targets and metalloprotease activity of tetanus and botulism neurotoxins. Curr Top Microbiol Immunol. 1995;195:257-274.

3 Sudhof TC. Synaptotagmins: why so many? J Biol Chem. 2002;277:7629-7632.

4 Shin OH, Rhee JS, Tang J, Sugita S, Rosenmund C, Sudhof TC. $\mathrm{Sr}^{2+}$ binding to the $\mathrm{Ca}^{2+}$ binding site of the synaptotagmin $1 \mathrm{C} 2 \mathrm{~B}$ domain triggers fast exocytosis without stimulating SNARE interactions. Neuron. 2003;37:99-108.

5 Chen YA, Duvvuri V, Schulman H, Scheller RH. Calmodulin and protein kinase $\mathrm{C}$ increase $\mathrm{Ca}^{2+}$-stimulated secretion by modulating membrane-attached exocytic machinery. J Biol Chem. 1999;274:26469-26476.

6 Quetglas S, Leveque C, Miquelis R, Sato K, Seagar M. $\mathrm{Ca}^{2+}$ dependent regulation of synaptic SNARE complex assembly via a calmodulin- and phospholipid-binding domain of synaptobrevin. Proc Natl Acad Sci USA. 2000;97:9695-9700.

7 Quetglas S, Iborra C, Sasakawa N, et al. Calmodulin and lipid binding to synaptobrevin regulates calcium-dependent exocytosis. EMBO J. 2002;21:3970-3979.

8 Neher E, Zucker RS. Multiple calcium-dependent processes related to secretion in bovine chromaffin cell. Neuron. 1993; 10:21-30.

9 Stevens CF, Tsujimoto T. Estimates for the pool size of releasable quanta at a single central synapse and for the time required to refill the pool. Proc Natl Acad Sci USA. 1995;92:846-849.

10 Bittner MA, Holz RW. Kinetic analysis of secretion from permeabilized adrenal chromaffin cells reveals distinct components. J Biol Chem. 1992;267:16219-16225.

11 Banerjee A, Barry VA, DasGupta BR, Martin TFJ. N-Ethylmaleimide-sensitive factor acts at a prefusion ATP-dependent step in $\mathrm{Ca}^{2+}$-activated exocytosis. J Biol Chem. 1996;271: 20223-20226.

12 Misonou H, Nishiki T, Sekiguchi M, et al. Dissociation of SNAP-25 and VAMP-2 by MgATP in permeabilized adrenal chromaffin cells. Brain Res. 1996;737:351-355.

13 Hay JC, Fisette PL, Jenkins GH, et al. ATP-dependent inositide phosphorylation required for $\mathrm{Ca}^{2+}$-activated secretion. Nature. 1995;374:173-177.

14 Kumakura K, Sasaki K, Sakurai T, et al. Essential role of myosin light chain kinase in the mechanism for MgATP-dependent priming of exocytosis in adrenal chromaffin cells. J Neurosci. 1994;14:7695-7703.

15 Ashery U, Varoqueaux F, Voets T, et al. Munc13-1 acts as a priming factor for large dense-core vesicles in bovine chromaffin cells. EMBO J. 2000;19:3586-3596.

16 Greengard P, Valtorta F, Czernik AJ, Benfenati F. Synaptic vesicle phosphoproteins and regulation of synaptic function. Science. 1993;259:780-785.

17 Vaughan PF, Walker JH, Peers C. The regulation of neurotransmitter secretion by protein kinase. Mol Neurobiol. 1998;18:125-155.

18 Jovanovic JN, Benfenati F, Siow YL, et al. Neurotrophins stimulate phosphorylation of synapsin I by MAP kinase and regulate synapsin I-actin interactions. Proc Natl Acad Sci USA. 1996;93:3679-3683.

19 Amino S, Itakura M, Ohnishi $\mathrm{H}$, et al. Nerve growth factor enhances neurotransmitter release from $\mathrm{PC} 12$ cells by increasing $\mathrm{Ca}^{2+}$-responsible secretory vesicles through the activation of mitogen-activated protein kinase and phosphatidylinositol 3kinase. J Biochem. 2002;131:887-894.

20 Fletcher AI, Shuang R, Giovannucci DR, Zhang L, Bittner MA, Stuenkel EL. Regulation of exocytosis by cyclin-dependent kinase 5 via phosphorylation of Munc18. J Biol Chem. 1999;274:4027-4035.

21 Yang F, He X, Feng L, et al. PI-3 kinase and IP3 are both necessary and sufficient to mediate NT3-induced synaptic potentiation. Nat Neurosci. 2001;4:19-28.

22 Takahashi M, Ohnishi H. Negative regulation of exocytosis at the nerve terminal. Mol Psychiatry. 2002;7:536-537.

23 Newton AC, Johnson JE. Protein kinase C: a paradigm for regulation of protein function by two membrane-targeting modules. Biochim Biophys Acta. 1998;1376:155-172.

24 Majewski H, Iannazzo L. Protein kinase C: a physiological mediator of enhanced transmitter output. Prog Neurobiol. 1998;55:463-475.

25 Hilfiker S, Augustine GJ. Regulation of synaptic vesicle fusion by protein kinase C. J Physiol (Lond). 1999;515:1.

26 Searl TJ, Silinsky EM. Increases in acetylcholine release produced by phorbol esters are not mediated by protein kinase $\mathrm{C}$ at motor nerve endings. J Pharmacol Exp Ther. 1998;285:247251.

27 Iwasaki S, Kataoka M, Sekiguchi M, Shimazaki Y, Sato K, Takahashi M. Two distinct mechanisms underlie the stimulation of neurotransmitter release by phorbol esters in clonal rat pheochromocytoma PC12 cells. J Biochem. 2000;128:407-414.

28 Hall C, Monfries C, Smith P, et al. Novel human brain cDNA encoding a $34,000 \mathrm{Mr}$ protein n-chimaerin, related to both the regulatory domain of protein kinase $\mathrm{C}$ and $\mathrm{BCR}$, the product of the breakpoint cluster region gene. J Mol Biol. 1990;211:11-16.

29 Betz A, Ashery U, Rickmann M, et al. Munc13-1 is a presynaptic phorbol ester receptor that enhances neurotransmitter release. Neuron. 1998;21:123-136.

30 Ozaki N, Shibasaki T, Kashima Y, et al. cAMP-GEFII is a direct target of cAMP in regulated exocytosis. Nat Cell Biol. 
2000;2:805-811.

31 Augustin I, Betz A, Herrmann C, Jo T, Brose N. Differential expression of two novel Munc13 proteins in rat brain. Biochem J. 1999;337:363-371.

32 Augustin I, Rosenmund C, Sudhof TC, Brose N. Munc13-1 is essential for fusion competence of glutamatergic synaptic vesicles. Nature. 1999;400:457-461.

33 Betz A, Okamoto M, Benseler F, Brose N. Direct interaction of rat unc-13 homologue Munc13-1 with the $\mathrm{N}$ terminus of syntaxin. J Biol Chem. 1997;272:2520-2526.

34 Orita S, Naito A, Sakaguchi G, et al. Physical and functional interactions of Doc2 and Munc13 in $\mathrm{Ca}^{2+}$-dependent exocytotic machinery. J Biol Chem. 1997;272:16081-16084.

35 Rhee JS, Betz A, Pyott S, et al. Beta phorbol ester- and diacylglycerol-induced augmentation of transmitter release is mediated by Munc13s and not by PKCs. Cell. 2002;108:121-133.

36 Gillis KD, Mossner R, Neher E. Protein kinase C enhances exocytosis from chromaffin cells by increasing the size of the readily releasable pool of secretory granules. Neuron. 1996;16:1209-1220.

37 Tsuboi T, Kikuta T, Warashina A, Terakawa S. Protein kinase C-dependent supply of secretory granules to the plasma membrane. Biochem Biophys Res Commun. 2001;282:621-628.

38 Shoji-Kasai Y, Itakura M, Kataoka M, Yamamori S, Takahashi M. Protein kinase $\mathrm{C}$-mediated translocation of secretory vesicles to plasma membrane and enhancement of neurotransmitter release from PC12 cells. Eur J Neurosci. 2002;15:1390-1394.

39 Stevens CF, Sullivan JM. Regulation of the readily releasable vesicle pool by protein kinase C. Neuron. 1988;21:885-893.

40 Yawo $\mathrm{H}$. Protein kinase $\mathrm{C}$ potentiates transmitter release from the chick ciliary presynaptic terminal by increasing the exocytotic fusion probability. J Physiol (Lond). 1999;515:169-180.

$41 \mathrm{Wu}$ XS, Wu LG. Protein kinase C increases the apparent affinity of the release machinery to $\mathrm{Ca}^{2+}$ by enhancing the release machinery downstream of the $\mathrm{Ca}^{2+}$ sensor. J Neurosci. 2001; 21:7928-7936.

$42 \mathrm{Zhu} \mathrm{H}$, Hille B, Xu T. Sensitization of regulated exocytosis by protein kinase C. Proc Natl Acad Sci USA. 2002;99:1705517059.

43 Shimazaki Y, Nishiki T, Omori A, et al. Phosphorylation of 25-kDa synaptosome-associated protein. Possible involvement in protein kinase $\mathrm{C}$-mediated regulation of neurotransmitter release. J Biol Chem. 1996;271:14548-14553.
44 Gonelle-Gispert C, Costa M, Takahashi M, Sadoul K, Halban P. Phosphorylation of SNAP-25 on serine-187 is induced by secretagogues in insulin-secreting cells, but is not correlated with insulin secretion. Biochem J. 2002;368:223-232.

45 Kataoka M, Kuwahara R, Iwasaki S, Shoji-Kasai Y, Takahashi M. Nerve growth factor-induced phosphorylation of SNAP-25 in PC12 cells: a possible involvement in the regulation of SNAP-25 localization. J Neurochem. 2000;74:2058-2066.

46 Genoud S, Pralong W, Riederer BM, Eder L, Catsicas S, Muller D. Activity-dependent phosphorylation of SNAP-25 in hippocampal organotypic cultures. J Neurochem. 1999;72:1699-1706.

47 Nagy G, Matti U, Nehring RB, et al. Protein kinase C-dependent phosphorylation of synaptosome-associated protein of $25 \mathrm{kDa}$ at $\mathrm{Ser}^{187}$ potentiates vesicle recruitment. J Neurosci. 2002;22: 9278-9286.

48 Vitale ML, Seward EP, Trifaro JM. Chromaffin cell cortical actin network dynamics control the size of the release-ready vesicle pool and the initial rate of exocytosis. Neuron. 1995; 14:353-363.

49 Rose SD, Lejen T, Zhang L, Trifaro JM. Chromaffin cell F-actin disassembly and potentiation of catecholamine release in response to protein kinase $\mathrm{C}$ activation by phorbol esters is mediated through myristoylated alanine-rich $\mathrm{C}$ kinase substrate phosphorylation. J Biol Chem. 2001;276:36757-36763.

50 Breukel AI, Wiegant VM, Lopes da Silva FH, Ghijsen WE. Presynaptic modulation of cholecystokinin release by protein kinase $\mathrm{C}$ in the rat hippocampus. J Neurochem. 1998;70:341348.

51 Cousin MA, McLaughlin M, Nicholls DG. Protein kinase C modulates field-evokedtransmitter release from cultured rat cerebellar granule cells via a dendrotoxin-sensitive $\mathrm{K}^{+}$channel. Eur J Neurosci. 1999;11:101-109.

52 Fujita Y, Sasaki T, Fukui K, et al. Phosphorylation of Munc-18 $/ \mathrm{n}-\mathrm{Sec} 1 / \mathrm{rbSec} 1$ by Protein Kinase C. J Biol Chem. 1996; 271:7265-7268.

53 Capogna M, Fankhauser C, Gagliardini V, Gahwiler BH, Thompson SM. Excitatory synaptic transmission and its modulation by PKC is unchanged in the hippocampus of GAP-43deficient mice. Eur J Neurosci. 1999;11:433-440.

54 Fykse EM. Depolarization of cerebellar granule cells increases phosphorylation of rabphilin-3A. J Neurochem. 1998;71:16611669. 